\title{
Bibliometry of the Revista de Biología Tropical / International Journal of Tropical Biology and Conservation: document types, languages, countries, institutions, citations and article lifespan
}

\author{
Julián Monge-Nájera ${ }^{1} \&$ Yuh-Shan $\mathrm{Ho}^{2 *}$ \\ 1. Laboratorio de Ecología Urbana, Vicerrectoría de Investigación, Universidad Estatal a Distancia, 2050 San José, Costa \\ Rica; julianmonge@gmail.com \\ 2. Trend Research Centre, Asia University, Taichung 41354, Taiwan; ysho@asia.edu.tw \\ * Correspondence
}

Received 01-XII-2015. Corrected 10-V-2016. Accepted 08-VI-2016.

\begin{abstract}
The Revista de Biología Tropical / International Journal of Tropical Biology and Conservation, founded in 1953, publishes feature articles about tropical nature and is considered one of the leading journals in Latin America. This article analyzes document type, language, countries, institutions, citations and -for the first time- article lifespan, from 1976 through 2014. We analyzed 3978 documents from the Science Citation Index Expanded. Articles comprised $88 \%$ of the total production and had 3.7 citations on average, lower than reviews. Spanish and English articles were nearly equal in numbers, and citation for English articles was only slightly higher. Costa Rica, Mexico, and the USA are the countries with more articles, and the leading institutions were Universidad de Costa Rica, Universidad Nacional, Universidad Nacional Autónoma de Mexico and Universidad de Oriente (Venezuela). The citation lifespan of articles is long, around 37 years. It is not surprising that Costa Rica, Mexico, and Venezuela lead in productivity and cooperation, because they are mostly covered by tropical ecosystems and share a common culture and a tradition of scientific cooperation. The same applies to the leading institutions, which are among the largest Spanish language universities in the neotropical region. American output can be explained by the regional presence of the Smithsonian Tropical Research Institute and the Organization for Tropical Studies. Tropical research does not have the rapid change typical of medical research, and for this reason, the impact factor misses most of citations for the Revista, which are made after the two-year window used by the Web of Science. This issue is especially damaging for the Revista because most journals that deal with tropical biology are never checked when citations are counted by the Science Citation Index. Rev. Biol. Trop. 64 (3): 1223-1235. Epub 2016 September 01.
\end{abstract}

Key words: bibliometrics, scientometrics, citations, Impact Factor, Revista de Biología Tropical, SCI-EXPANDED.

The Revista de Biología Tropical/International Journal of Tropical Biology and Conservation is a scientific journal that has been printed since 1953 and basically publishes feature articles from Latin America, the USA, Europe, tropical Africa and Asia. With a $70 \%$ rejection rate and an output of 3000 pages per volume, the Revista is considered one of the leading journals in Latin America (MongeNájera \& Díaz, 1988; Monge-Nájera \& Ho, 2012; De Filippo González \& Sanz-Casado, 2016). The first bibliometric study of the journal was published to celebrate its $35^{\text {th }}$ anniversary and covered main publication topics, rejection rate, origin and language of manuscripts, and number of authors per article (Monge-Nájera \& Díaz, 1988). It found that the main topics were animal taxonomy, biomedicine and ecology; that $50 \%$ of articles originated in Costa Rica; that one-half of the papers were in English, and that papers had a mean of 1.79 authors (MongeNájera \& Díaz, 1988).

The second study covered the Revista for the period 2000-2010 but only included 
articles about biodiversity, considering publication topics, language and, for the first time, collaboration among researchers, countries and institutions (Nielsen-Muñoz, Azofeifa-Mora, \& Monge-Nájera, 2012). It found that zoology represented $62 \%$ of articles; that $54 \%$ were in English; that $36 \%$ included international collaboration, and that the number of authors per paper had increased to 2.53. It was the first article to state that the real impact factor of the journal was unknown because it was cited mostly in journals not checked by the Science Citation Index to count citations (Nielsen-Muñoz, Azofeifa-Mora, \& Monge-Nájera, 2012).

The third study covered the period 20032012 of the Revista and, like the second study, covered collaboration, countries, institutions and impact, but included articles about all topics published during that decade (De Filippo et al., 2016). This study also found that about one half of the papers were in English, but also reported a lower proportion of articles resulting from international collaboration (22\%). It also found that the top producers by country were Mexico, Costa Rica and Venezuela; and by institution the Universidad de Costa Rica, Universidad Nacional Autónoma de México and Universidad de Puerto Rico. The number of authors per paper was even higher than in previous periods (3.07). This focused on citation in journals covered by the Science Citation Index, reporting that in those journals, Revista articles were cited a mean of one time in the two years following publication, and that the countries that most cite the Revista are USA, Brazil and Mexico. It also reported that $10 \%$ of the papers concentrated half of the citations in those journals, mostly published outside the tropics (De Filippo et al., 2016).

The decade of 1990 and recent years have not been studied previously. This article includes that missing decade and analyzes document type, language, countries, institutions, and for the first time, article lifespan.

\section{MATERIALS AND METHODS}

Documents used in this study were derived from the Science Citation Index Expanded
(SCI-EXPANDED) database of the Web of Science Core Collection, Thomson Reuters. The keyword phrase "Revista de Biología Tropical" was searched as publication name based on SCI-EXPANDED (updated on 13 August 2015). A total 3978 documents from 1976 to 2014 were found and downloaded for analysis. The acronym of bibliometric indicators and terms used are given in Digital Appendix 1. The analysis was done with citation related indicators $\left(I F_{2014}, C P P, T C_{2014}\right.$, and $\left.C_{2014}\right)$, and quantity related indicators $(T P, S P, C P$, $F P$, and $R P$ ). $T C_{2014}$ and $C_{2014}$ are recently developed indicators to assess the citations of articles by Ho and co-workers (Chuang, Olaiya \& Ho, 2011; Ho, 2012). The index of citation from Web of Science Core Collection was updated as time goes on. By comparison, $T C_{2014}$ was an invariable parameter to ensure repeatability to provide more scientific and accurate information (Chuang \& Ho, 2014). One article's $C_{2014}$ is calculated to identify the latest (it is 2014 in this study) and the most influential research. In the SCI-EXPANDED database, the corresponding author was designated as the "reprint" author; this study instead used the term "corresponding author" (Ho, 2012). In a single author article where authorship was unspecified, the single author was both first author and corresponding author (Ho, 2012). Similarly, for a single institution article, the institution was classified as the first author's institution and the corresponding author's institution (Ho, 2014). Articles originating from England, Scotland, Northern Ireland, and Wales were reclassified as being from the United Kingdom (UK) (Chiu \& Ho, 2005). Articles from Federal Republic of Germany (Fed Rep Ger) and Germany were reclassified as being from Germany (Ho, 2012).

Collaboration type of country and institution was determined by the addresses of the authors. The articles were classified by four types for country and institution (Fu \& Ho, 2015a). (1) The term "single country article" was assigned if the researchers' addresses were from the same country. The term "single institution article" was assigned if the researchers' 
addresses were from the same institution. (2) The term "internationally collaborative article" was designated to those articles that were coauthored by researchers from multiple countries. The term "inter-institutionally collaborative article" was assigned if authors were from different institutions. "Inter-institutionally collaborative articles" included "internationally collaborative articles". (3) The term "first author article" was assigned to the articles for the analyzed country or institution, if the address of first author was listed from the analyzed item. For example, if the first author of an article listed the USA as his or her address, the article was assigned to one "first author article" of the USA. (4) Similarly, the term "corresponding author article" was assigned to the articles for the analyzed country or institution, if the address of the corresponding author was listed from the analyzed item. All document information was downloaded from SCIEXPANDED database into Microsoft Excel 2010 (Li \& Ho, 2008).

\section{RESULTS}

Document types and citations: There were 4098 papers published in Revista de Biología Tropical (Rev Biol Trop) from 1976 to 2014 (Table 1). The information of document types were obtained from Web of Science, and therefore the analyzed document types were the same as those used in Web of Science. Articles $(\mathrm{N}=3587)$ were the dominant document type, comprising $88 \%$ of the total production, but they only had the third ranking of CPP (3.7 citations on average). Reviews (representing $1.6 \%$ of all documents) held the highest $C P P$ among these 12 document types, with an average of 9.5 citations per review. The following document type was notes $(5.6 \%)$ with the $4^{\text {th }}$ ranking of $C P P$ (2.5 citations on average), and then proceedings papers $(2.9 \%)$. Since they were the dominant type of document, only articles were used for further analysis covering publication outputs, contributors by countries and institutions, and citation life cycles of the most cited articles (Ho, Satoh, \& Lin, 2010).

Languages and citations: The predominant language for journal articles was Spanish (1947; $54 \%$ of 3587 ) with $C P P$ of 3.0 citations, followed by English $(1623 ; 45 \%)$ with $C P P$ of 4.5 , Portuguese $(10 ; 0.28 \%)$ with $C P P$ of 3.4 , and French $(7 ; 0.20 \%)$ with $C P P$ of 6.0. Thirty percent of Spanish articles lacked citations $\left(T C_{2014}=0\right), 20 \%$ articles had only one citation $\left(T C_{2014}=1\right)$, and $14 \%$ articles had two citations $\left(T C_{2014}=2\right)$ in the Web of Science Core Collection, while $22 \%, 18 \%$,

TABLE 1

Document types for Revista de Biología Tropical (1976-2014)

\begin{tabular}{lccc}
\multicolumn{1}{c}{ Document type } & Total number of articles & Total citations to the end of 2014 & Citations per publication \\
Article & 3587 & 13134 & 3.7 \\
Note & 230 & 579 & 2.5 \\
Proceedings paper & 120 & 522 & 4.4 \\
Review & 66 & 629 & 9.5 \\
Editorial material & 52 & 15 & 0.29 \\
Biographical-item & 13 & 0 & 0 \\
Reprint & 10 & 2 & 0.20 \\
Correction & 8 & 1 & 0.13 \\
Letter & 5 & 1 & 0.20 \\
Item about an individual & 4 & 0 & 0 \\
Addition correction & 2 & 0 & 0 \\
Bibliography & 1 & 0 & 0 \\
Total & 4098 & & 0 \\
\hline
\end{tabular}


and $12 \%$ of 1623 English articles had $T C_{2014}$ $=0, T C_{2014}=1$, and $T C_{2014}=2$, respectively. Briefly, articles in English had a slightly higher number of citations (Fig. 1). Only two articles had over 100 citations to 2014: "Ecophysiological adaptability of tropical aquatic organisms to salinity changes" (Chung, 2001) in Spanish $\left(T C_{2014}=108\right)$ and "Rapid spread of diseases in Caribbean coral reefs" (Goreau et al., 1998) in English $\left(T C_{2014}=106\right)$.

Countries and institutions: Costa Rica, Mexico, and the USA are the countries with more articles (Table 2, Fig. 2). For the period 1975 through 1990 the SCI-EXPANDED includes a lower number of articles, but the period 1992-2009 has a much higher number of papers; in this period there seems to be a cycle of large oscillations. After 2010 the presence of Costa Rica and the USA declined, and that of Mexico increased (Fig. 2).
The institutions with most papers are two Costa Rican and two foreign institutions: from Costa Rica the Universidad de Costa Rica and the Universidad Nacional, and foreign Universidad Nacional Autónoma from Mexico and Universidad de Oriente from Venezuela (Table 3, Fig. 3). The pattern for institutions is similar to the pattern for countries, a lower block from 1975 through 1995 and a higher number of articles for 1996-2009 marked by large oscillations. Similar to the countries too is the general reduction of articles from those institutions after 2009.

Articles show two stages, a lower value before 1995 and a much higher value after that year. Citations generally oscillate between 3 and 6 citations per article and this trend did not change during the second stage with much higher number of articles, but there is an unusually high number of citations that can be attributed to the series by Dressler about

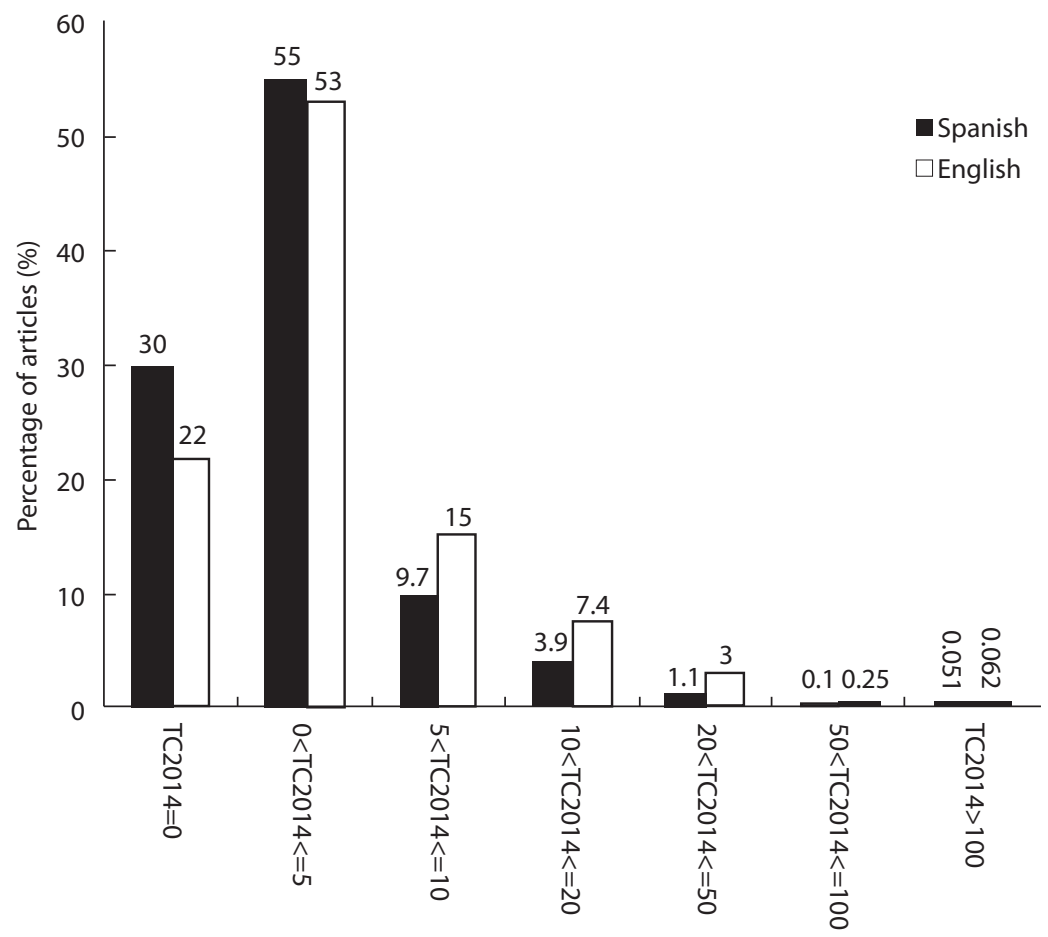

Fig. 1. Language versus number of citations in the SCI-EXPANDED. 


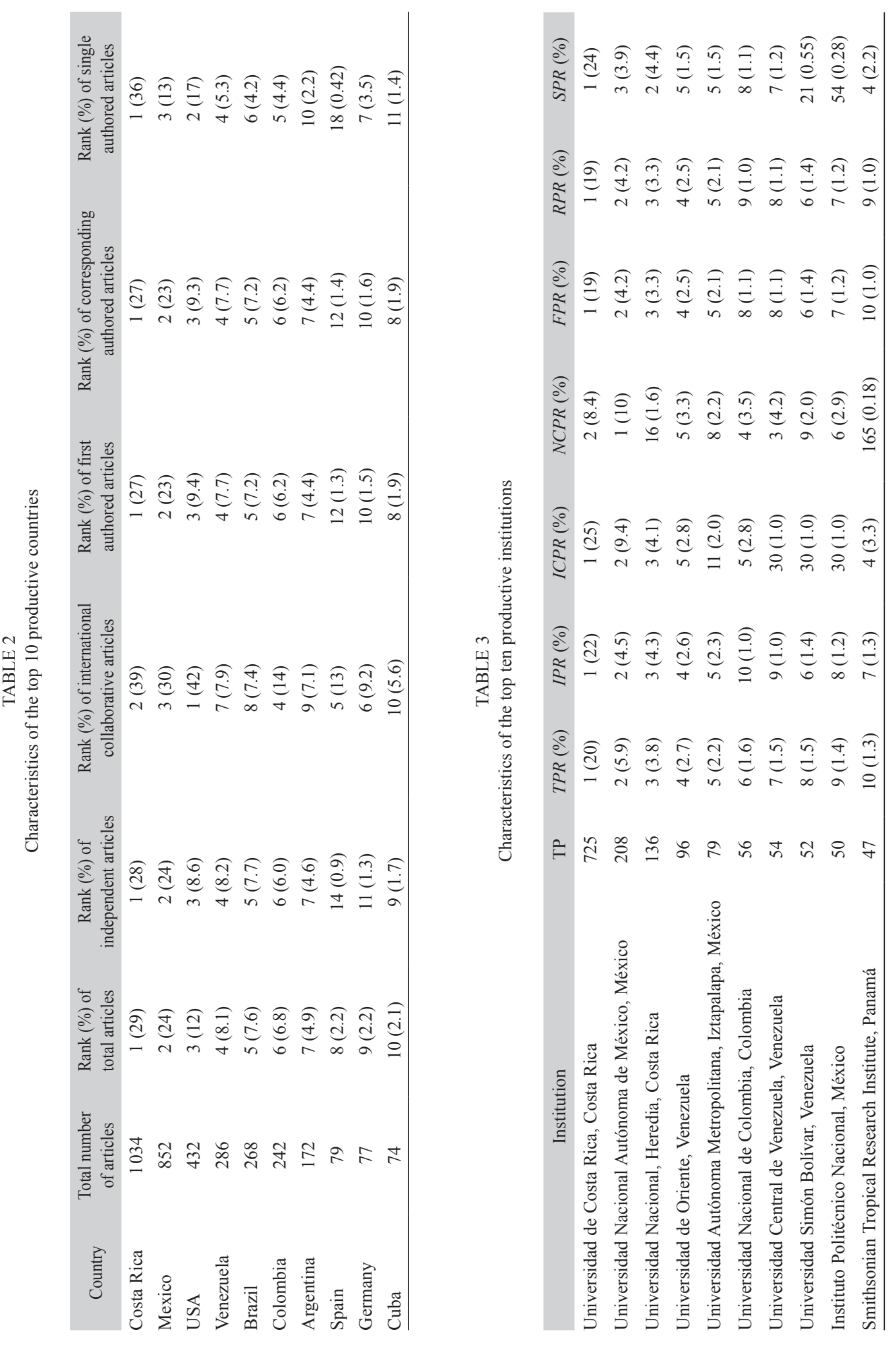




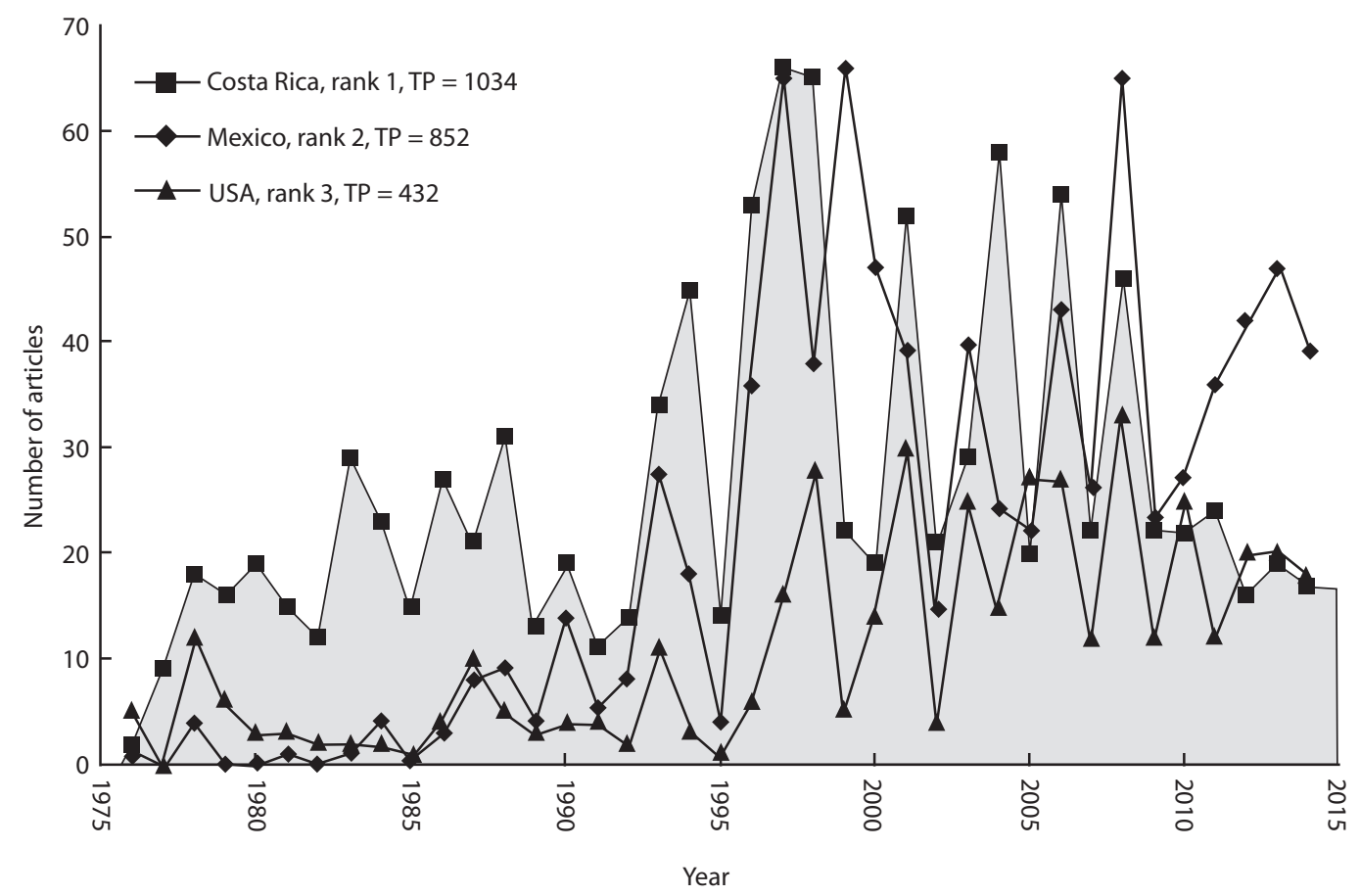

Fig. 2. Number of articles versus year for the three countries that dominate authorship in the Revista de Biología Tropical.

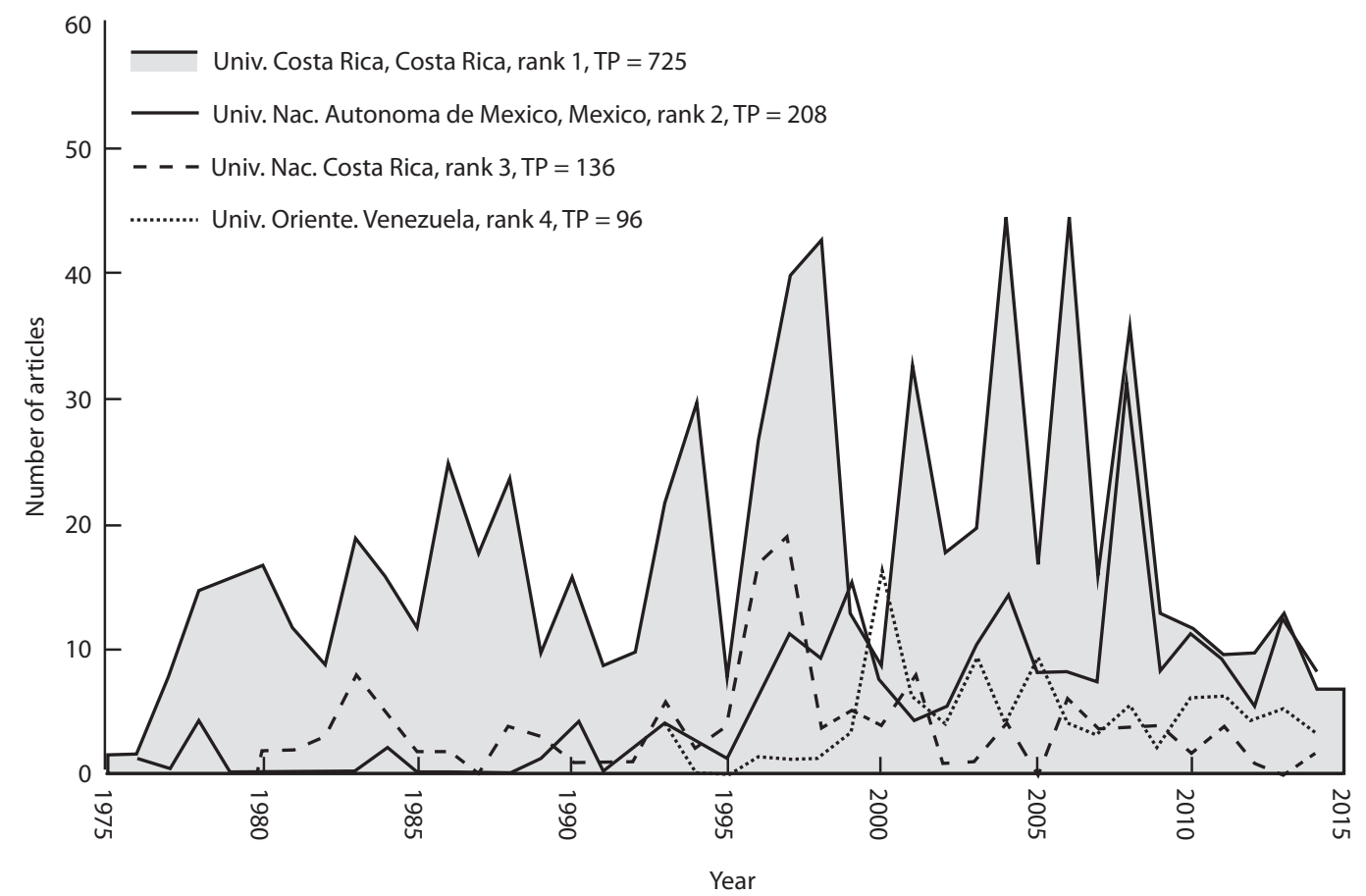

Fig. 3. Number of articles versus year for the four institutions that dominate authorship in the Revista de Biología Tropical. 
tropical stingless bee biodiversity: "New Species of Euglossa. 2. (Hymenoptera, Apidae)" (Dressler, 1982a) with $T C_{2014}$ of 35 and ranked 22, "New Species of Euglossa. 3. the Bursigera Species Group (Hymenoptera, Apidae)" (Dressler, 1982b) with $T C_{2014}$ of 37 and ranked 19, and "New Species of Euglossa. 4. the Cordata and Purpurea Species Groups (Hymenoptera, Apidae)" (Dressler, 1982c) with $T C_{2014}$ of 35 and ranked 19 (Fig. 4; Digital Appendix 2 presents a detail of the most cited articles). The reduction of citations after 2008 reflects the fact that articles have a long lifespan and receive most citations after the first two years used by the Web of Science, so there has not been enough time for citations to accumulate. Actually, most citations in the SCI for this journal occur seven years after publication (Fig. 4).
When only the most frequently cited articles are considered, citation from 1997 through 2002 is lower, around 0.12 citations on average; from 2003 through 2008 there is a second period around 0.20 citations on average, and a third period, 2009 to present, that reaches a highest value of 0.61 citations on average; so the general trend is towards a higher impact (Fig. 5).

The citation lifespan of articles in this journal is long, around 37 years (Fig. 6).

\section{DISCUSSION}

From a scientometric point of view, the USA is generally found to be the leader in all scientific fields and in fields like Corporate

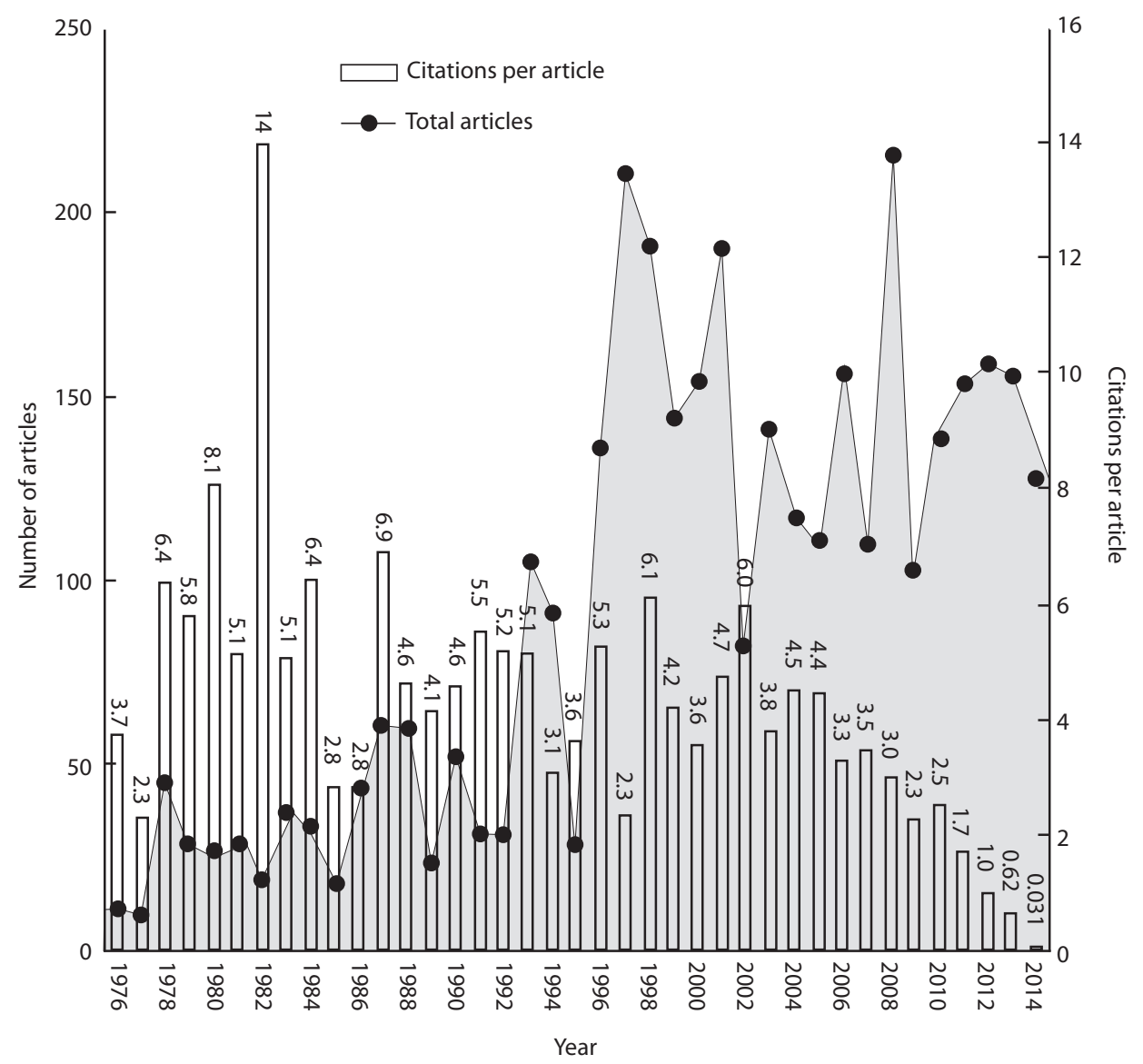

Fig. 4. Number of articles versus citations and year for Revista de Biología Tropical. 


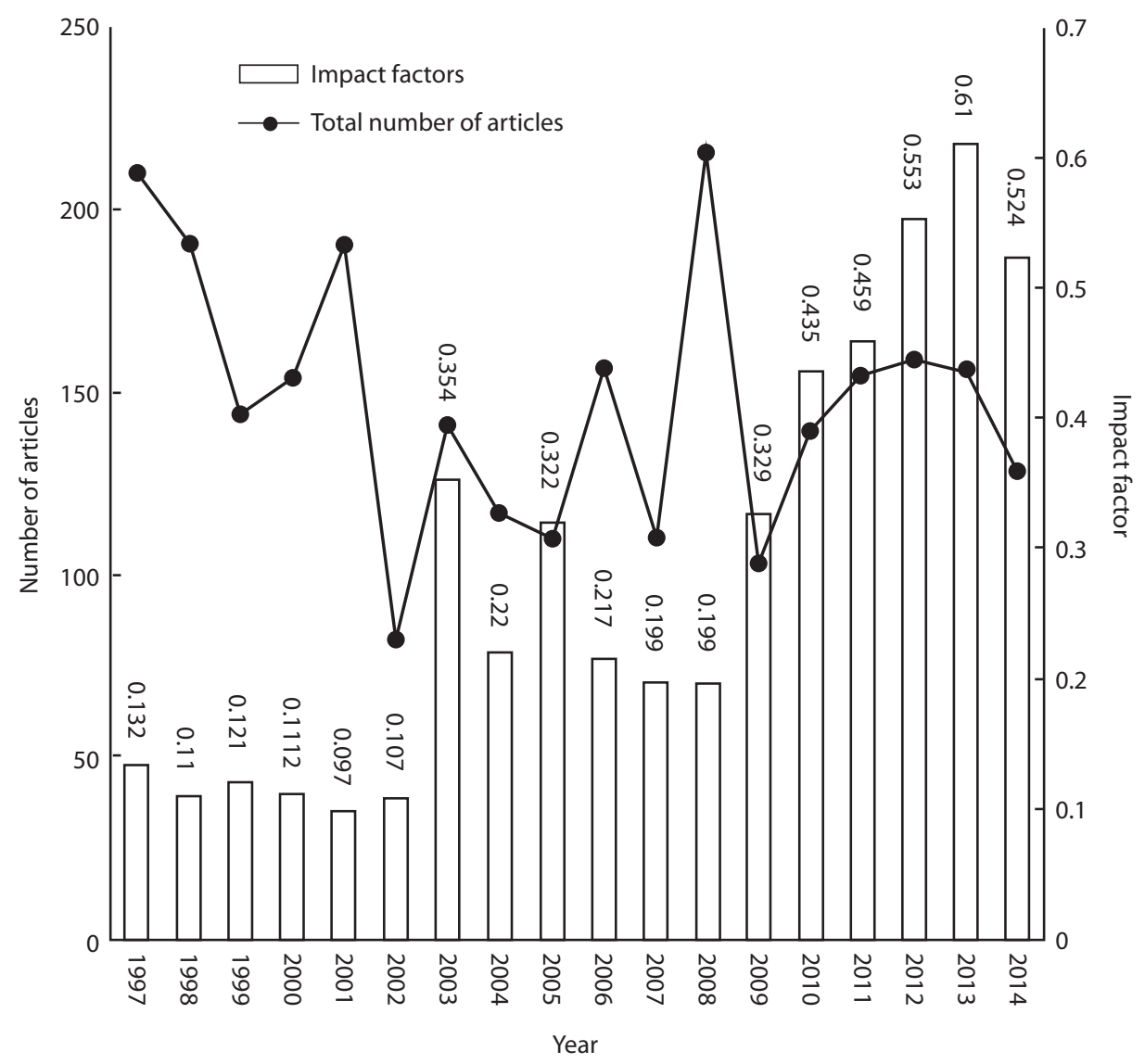

Fig. 5. Citation life cycles of most frequently cited articles in the Revista de Biología Tropical.

Governance; there is little presence of other regions or cross-national research (Durisin \& Puzone, 2009). Nevertheless, this situation is changing in recent years: some Asian countries, and Brazil in Latin America, are beginning to show a significant growth (Sundell \& Nazaroff, 2009; Ronda \& Guerras, 2010). Our results agree with those findings from studies of other international journals: after Costa Rica and Mexico, the country with most production in the Revista is the USA. This is true despite the fact that most of the territory of the USA is outside the tropical belt, but American scientists work in tropical areas, both independently and as part of the Smithsonian Tropical Research Institute (Monge-Nájera \& Ho, 2015) or the Organization for Tropical Studies
(Monge-Nájera, Nielsen-Muñoz \& AzofeifaMora; 2013). The reduction in the number of papers from Costa Rica in recent years may result from tightened standards in the journal and that space seem to be filling up with an increased presence of Brazilian articles in recent issues (JMN personal observation).

Previous studies with other journals have reported that authors establish de facto networks that collaborate and repeatedly cite each other (Ronda \& Guerras, 2010; Fatt, Abu Ujum \& Ratnavelu, 2010; Schulz \& Nicolai, 2015), and that neighboring countries share interests and collaborate in certain research topics (Yarime, Takeda \& Kajikawa, 2010). Our results suggest that this shared interest research takes place in the cases of Mexico, Venezuela 


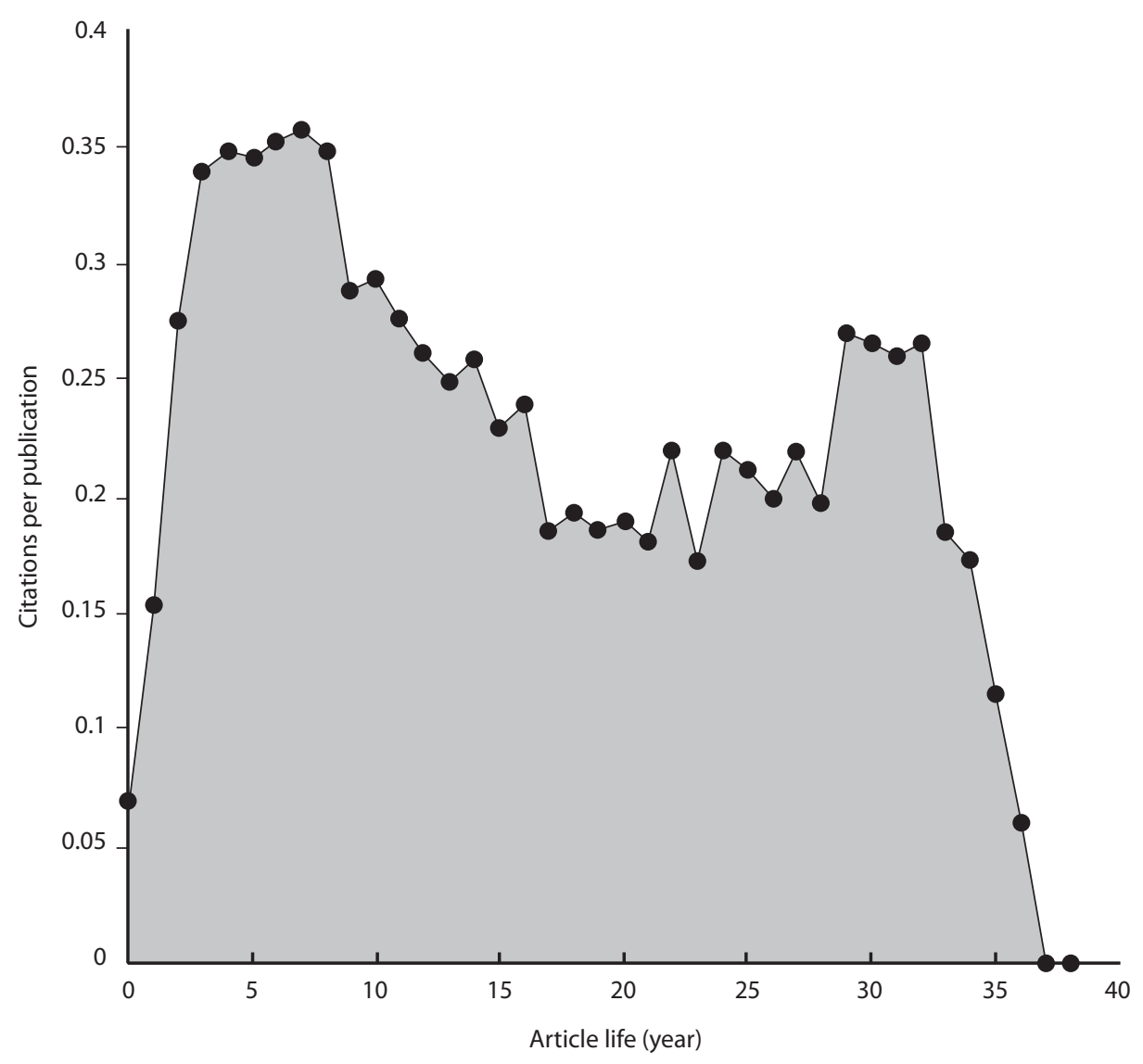

Fig 6. Citation lifespan of articles in the Revista de Biologia Tropical.

and Costa Rica, which are mostly covered by tropical ecosystems, share a common language (Spanish) and often collaborate in research (De Filippo, González, \& Sanz-Casado, 2016). The same applies to the leading institutions, which are among the largest Spanish language universities in the neotropical region, in which the journal focuses.

This common language and interest in the neotropical region can also explain why Spanish language articles are not very different from English language articles in number of publications or citations received (Monge-Nájera \& Nielsen, 2005).

There are few studies about cycles in scientific productivity (e.g. Szydlowski \& Krawiec, 2004) and none seems to explain the clear temporal cycles in number of articles published each year by particular countries and institutions that we found in this journal. Such cycles might simply reflect the coordination in holiday periods during which researchers stop working, which are the same all over Latin America. To future researchers we propose the hypothesis that authors try to finish articles before the end of year vacation and start new projects at the beginning of the next year; this would result in a cycle in the publication dates for their production.

The impact factor as measured by the Web of Science was never meant to be used as an evaluation of the importance of research, and originally it had no financial influence: funding was unrelated to citations (Harter \& Hooten, 1992; Gregory, 2004). Nevertheless, this factor is now used to decide who gets funds and 
positions (Monge-Nájera, 2014). Even though we will refer to it in this discussion, it must be born in mind that the impact factor has been challenged with increased frequency in recent years. For example, calculation assumes that citation data are reliable and available for scientific scrutiny, yet bibliographic errors are frequent (Spivey \& Wilks, 2001) and the citation data are not transparent (San Francisco Declaration on Research, www.ascb.org/dora).

Several authors have reported that, generally, reviews and classic papers are the most cited, with exceptions like consumer research, and environmental and occupational health, fields in which some applied topics get the most citations (Cote, Leong, \& Cote, 1991; Smith, 2009; Monge-Nájera \& Ho, 2012). Other trends have been reported as well, including innovation research, in which rigorous analysis of old topics and novel topics dominate citations, and computer-aided molecular design, in which descriptions of software and methods are the most cited (Durisin, Calabretta, \& Parmeggiani, 2010; Willet, 2012). In the case of the Revista, we found that reviews have a higher impact factor than original research papers, which is in agreement with the general trend.

To measure impact, citations are only counted during a two-year window for all fields, even though in many fields most -if not all citations- occur after that period. This has been found to be a methodological problem in fields as varied as indoor air (Sundell \& Nazaroff, 2009), membrane science (Fu \& Ho, 2015b) and tropical biology (Monge-Nájera \& Ho, 2015). In the case of the Revista, we found the same problem: the two year window used to calculate the impact hides the real impact, which happens mostly after the Web of Science stops counting citations. This is particularly serious for the Revista because most of the citations occur along a period of three decades and because most of the journals that deal with tropical biology are never checked by the Science Citation Index to count the citations (Monge-Nájera, 2014). Considering this problem, it has been recommended that researchers, educators and administrators used the so called "non-core journals" to get a wider and more representative view of science (Crawley-Low, 2006) and that they check the quality of the articles themselves, which may or may not be related to the impact factor (Jones, 1999). In fact, in some cases, high citation values may be indicative of an article that is controversial or clearly wrong (Morley, 2002; Monge-Nájera \& Ho, 2015).

The Revista de Biología Tropical is the only Central American scientific journal that is considered fit for inclusion in the SCIEXPANDED by the Web of Science. This is particularly interesting, because the region publishes more than 800 scientific and technical journals (www.latindex.unam.mx).

Many scientometric studies have considered the question of why some journals succeed in becoming international, and of course, editorial quality in all aspects is an absolute requisite. Having a local name appears to be negative; for example, journals whose name and authorship remain local despite efforts to attract foreign authors include the Acta Botanica Croatica, Brazilian Journal of Medical and Biological Research or Australasian Plant Pathology (Jokić \& Sirotić, 2002; Krieger \& Ferreira, 2003; Calver, O’Brien, \& Lilith, 2012; Carreño, Poutou., Mattar, \& González, 2009; Villar, Estrada, Pérez, \& Rebollo, 2007). Possibly, thanks to the prestige of American science, journals with the word American in their name do not seem to suffer from the negative "provincial" association (e.g. Kanavakis et al., 2006).

On the other hand, besides their quality, journals that succeeded in attracting international authors and readers have general names or even include the word "international" in their names, like Journal of Clinical Pathology or International Journal of Clinical and Health Psychology (Chuang et al., 2012; Yalçin, 2010). In the case studied here, both conditions are met: the journal has a general name (Revista de Biología Tropical means Journal of Tropical Biology) and the subtitle includes the word international: International Journal of Tropical Biology and Conservation. In this aspect, the vision of those who founded the journal with 
an international outlook, that was most rare in the region at the time (Editorial in vol. 1 issue 1, January 1953), has paid in making the Revista a respected international medium for the diffusion of new knowledge on the most endangered subjects of our time, the tropical ecosystems of the world.

\section{ACKNOWLEDGMENTS}

We thank Carlos Morales for corrections to the text and Alonso Prendas for his help with the figures.

\section{RESUMEN}

Bibliometría de la Revista de Biología Tropical: tipos de documento, idiomas, países, instituciones, citas y longevidad de los artículos. La Revista de Biología Tropical/International Journal of Tropical Biology and Conservation, fundada en 1953, publica artículos de fondo sobre la naturaleza tropical y es considerada una de las revistas líderes en América Latina. Este artículo considera tipos de documentos, idioma, países, instituciones, citas y, por primera vez, longevidad de artículos. Analizamos 3978 documentos entre 1976 y 2014, del Science Citation Index Expanded (base de datos de la Web of Science). Los artículos representan $88 \%$ de la producción total y reciben en promedio 3.7 citas (las revisiones reciben más). Los artículos en español e inglés son casi iguales en número y citas recibidas (ligeramente más en los artículos en inglés). Costa Rica, México y EE.UU. son los países con más artículos y las principales instituciones son: Universidad de Costa Rica, Universidad Nacional (Heredia), Universidad Nacional Autónoma de México y Universidad de Oriente (Venezuela). Los artículos siguen siendo citados, en promedio, durante 37 años. No es de extrañar que Costa Rica, México y Venezuela dominen la productividad y la cooperación, porque están cubiertos en su mayoría por ecosistemas tropicales, comparten una cultura y tienen una tradición de cooperación científica. Lo mismo ocurre con las instituciones líderes, que están entre las mayores universidades de lengua española en la región neotropical. La alta producción estadounidense se explica por la presencia regional del Instituto Smithsoniano de Investigaciones Tropicales y la Organización para Estudios Tropicales. La investigación tropical no tiene el rápido avance típico de la investigación médica, por lo que el factor de impacto falla al dejar por fuera la mayor parte de las citas que recibe la Revista, las cuales se producen después de los dos años que cubre Web of Science. Esto es particularmente desventajoso, porque Science Citation Index Expanded, al contar las citas, no revisa la mayoría de las revistas que se ocupan de la biología tropical.
Palabras clave: bibliometría, citas; factor de impacto, Revista de Biología Tropical, SCI-Expanded.

\section{REFERENCES}

Calver, M. C., O’Brien, P. A., \& Lilith, M. (2012). Australasian Plant Pathology: An analysis of authorship and citations in the 21 st century. Australasian Plant Pathology, 41(2), 179-187.

Carreño, L. M., Poutou-Piñales, R. A., Mattar, S., \& González, M. (2009). Bibliometric activity indicators for the Journal MVZ Córdoba 1994-2008. Revista MVZ Córdoba, 14(1), 1531-1543.

Chiu, W. T., \& Ho, Y. S. (2005). Bibliometric analysis of homeopathy research during the period of 1991 to 2003. Scientometrics, 63(1), 3-23.

Chuang, K. Y., \& Ho, Y. S. (2014). A bibliometric analysis on top-cited articles in pain research. Pain Medicine, 15(5), 732-744.

Chuang, K. Y., Olaiya, M. U., \& Ho, Y. S. (2012). Bibliometric analysis of the Polish Journal of Environmental Studies (2000-11). Polish Journal of Environmental Studies, 21(5), 1175-1183.

Chung, K. S. (2001). Ecophysiological adaptability of tropical aquatic organisms to salinity changes. Revista de Biología Tropical, 49(1), 9-13.

Cote, J. A., Leong, S. M., \& Cote, J. (1991). Assessing the influence of Journal of Consumer Research: A citation analysis. Journal of Consumer Research, 18(3), 402-410.

Crawley-Low, J. (2006). Bibliometric analysis of the American Journal of Veterinary Research to produce a list of core veterinary medicine journals. Journal of the Medical Library Association, 94(4), 430-434.

De Filippo, D., González, S. C., \& Sanz-Casado, E. (2016). Estudio bibliométrico de la colaboración e impacto de la Revista de Biología Tropical (Web of Science 2003-2012). Revista de Biología Tropical, 64(1), 147-156.

Dressler, R. L. (1982a). New species of Euglossa. II. (Hymenoptera, Apidae). Revista de Biología Tropical, 30(2), 121-129.

Dressler, R. L. (1982b). New species of Euglossa. III. The bursigera species group (Hymenoptera, Apidae). Revista de Biología Tropical, 30(2), 131-140.

Dressler, R. L. (1982c). New species of Euglossa. IV. The cordata and purpurea species groups (Hymenoptera, Apidae). Revista de Biología Tropical, 30(2), 141-150. 
Durisin, B., \& Puzone, F. (2009). Maturation of Corporate Governance Research, 1993-2007: An assessment. Corporate Governance, 17(3), 266-291.

Durisin, B., Calabretta, G., \& Parmeggiani, V. (2010). The intellectual structure of product innovation research: A bibliometric study of the Journal of Product Innovation Management, 1984-2004. Journal of Product Innovation Management, 27(3), 437-451.

Fu, H. Z., \& Ho, Y. S. (2015a). Top cited articles in thermodynamic research. Journal of Engineering Thermophysics, 24(1), 68-85.

Fu, H. Z., \& Ho, Y. S. (2015b). A bibliometric analysis of the Journal of Membrane Science (1976-2010). The Electronic Library, 33(4), 698-713.

Goreau, T. J., Cervino, J., Goreau, M., Hayes, R., Hayes, M., Richardson, L., Smith, G. \& Porter, K. (1998). Rapid spread of diseases in Caribbean coral reefs. Revista de Biología Tropical, 46(5S), 157-171.

Gregory, A. T. (2004). Jewels in the crown: The Medical Journal of Australia's 10 most-cited articles. The Medical Journal of Australia, 181(1), 9-12.

Harter, S. P., \& Hooten, P. A. (1992). Information-science and scientists: JASIS, 1972-1990. Journal of the American Society for Information Science, 43(9), 583-593.

Ho, Y.S. (2014) Classic articles on social work field in Social Science Citation Index: a bibliometric analysis. Scientometrics, 98,137-155.

Ho, Y. S. (2012). Top-cited articles in chemical engineering in Science Citation Index Expanded: A bibliometric analysis. Chinese Journal of Chemical Engineering, 20(3), 478-488.

Ho, Y. S., Satoh, H., \& Lin, S. Y. (2010). Japanese lung cancer research trends and performance in Science Citation Index. Internal Medicine, 49(20), 2219-2228

Jokić, M., \& Sirotić, G. (2002). The communicability of the journal Acta Botanica Croatica over the 1991-2000 period. Acta Botanica Croatica, 61(2), 221-230.

Jones, A. (1999). Invited special article. The impact of Alcohol and Alcoholism among substance abuse journals. Alcohol and Alcoholism, 34(1), 25-34.

Kanavakis, G., Spinos, P., Polychronopoulou, A., Eliades, T., Papadopoulos, M. A., \& Athanasiou, A. E. (2006). Orthodontic journals with impact factors in perspective: Trends in the types of articles and authorship characteristics. American Journal of Orthodontics and Dentofacial Orthopedics, 130(4), 516-522.

Krieger, E. M., \& Ferreira, S. H. (2003). Brazilian Journal of Medical and Biological Research 1981-2002.
Brazilian Journal of Medical and Biological Research, 36(1), 1-2.

Fatt, C. K., Abu Ujum, E., \& Ratnavelu, K. (2010). The structure of collaboration in the Journal of Finance. Scientometrics, 85(3), 849-860.

Li, Z., \& Ho, Y. S. (2008). Use of citation per publication as an indicator to evaluate contingent valuation research. Scientometrics, 75(1), 97-110.

Monge-Nájera, J. \& Díaz. L. (1988). Thirty-five years of Tropical biology: a quantitative history. Revista Biología Tropical, 36(2B), 347-359.

Monge-Nájera, J., \& Nielsen, V. (2005). The countries and languages that dominate biological research at the beginning of the $21^{\text {st }}$ century. Revista de Biologia Tropical, 53(1-2), 283-294.

Monge-Nájera, J. (2014). La invalidez del Factor de Impacto como indicador del impacto de las revistas científicas latinoamericanas. Revista de Biología Tropical, 62(1), 407-412.

Monge-Nájera, J., \& Ho, Y. S. (2012). Costa Rica publications in the Science Citation Index Expanded: A bibliometric analysis for 1981-2010. Revista de Biología Tropical, 60(4), 1649-1661.

Monge-Nájera, J., \& Ho, Y. S. (2015). Bibliometry of Panama publications in the Science Citation Index Expanded: Publication type, language, fields, authors and institutions. Revista de Biología Tropical, 63(4), 1255-1266.

Monge-Nájera, J., Nielsen-Muñoz, V., \& Azofeifa-Mora, A. B. (2013). Subject and authorship of records related to the Organization for Tropical Studies (OTS) in BINABITROP, a comprehensive database about Costa Rican biology. Revista de Biología Tropical, 61(2), 493-500.

Morley, J. E. (2002), Citations, impact factor, and the Journal. J. Gerontol. The Journals of Gerontology Series A: Biological Sciences and Medical Sciences, 57(12), M765-M769.

Nielsen-Muñoz, V., Azofeifa-Mora, A., \& Monge-Nájera, J. (2012). Bibliometry of Costa Rica biodiversity studies published in the Revista de Biología Tropical (2000-2010): the content and importance of a leading tropical biology journal in its 60th Anniversary. Revista de Biología Tropical, 60, 1405-1413.

Ronda-Pupo, G. A., \& Guerras-Martin, L. A. (2010). Dynamics of the scientific community network within the strategic management field through the Strategic Management Journal 1980-2009: the role of cooperation. Scientometrics, 85(3), 821-848.

Schulz, A. C., \& Nicolai, A. T. (2015). The intellectual link between management research and popularization media: A bibliometric analysis of the Harvard 
Business Review. The Academy of Management Learning and Education, 14(1), 31-49.

Smith, D. R. (2009). Highly cited articles in environmental and occupational health, 1919-1960. Archives of Environmental \& Occupational Health, 64(S1), 32-42.

Spivey, C. A., \& Wilks, S. E. (2004). Reference list accuracy in social work journals. Research on Social Work Practice, 14(4), 281-286.

Sundell, J., \& Nazaroff, W. W. (2009). The most cited articles in Indoor Air, through 18 years. Indoor Air, 19(2), 91-92.

Szydlowski, M., \& Krawiec, A. (2001). Scientific cycle model with delay. Scientometrics, 52(1), 83-95.
Villar, F., Estrada, J. M., Pérez, C., \& Rebollo, M. J. (2007). Bibliometric study of the original articles published in Revista Española de Salud Pública (1991-2000). Part III: reference analysis. Revista Española de Salud Pública, 81(3), 247-59.

Willett, P. (2012). The Journal of Computer-Aided Molecular Design: A bibliometric note. The Journal of Computer-Aided Molecular Design, 26(1), 153-157.

Yalçin, H. (2010). Bibliometric profile of Journal of National Folklore (2007-2009). Milli Folklor, 85, 205-211.

Yarime, M., Takeda, Y., \& Kajikawa, Y. (2010). Towards institutional analysis of Sustainability Science: A quantitative examination of the patterns of research collaboration. Sustainability Science, 5(1), 115-125.

\section{See Digital Appendix}


